\title{
The Use of Fiberglass and Ceramic Cylinders to Support the Root Pass in C-Steel Welds with a Double-V Groove
}

\author{
Ricardo Fernandes Gurgel ${ }^{1}$, Ronaldo Pinheiro da Rocha Paranhos ${ }^{2 *}$ \\ 1 Instituto Federal Fluminense, Campus Itaperuna, Itaperuna, RJ, Brazil. \\ 2 Laboratório de Materiais Avançados - LAMAV, Universidade Estadual do Norte Fluminense - UENF, Campos dos Goytacazes, \\ RJ, Brazil.
}

Received: 11 May, 2015

Accepted: 10 Aug., 2015

E-mails: ricardoiffuenf2013@gmail.com

(RFG), paranhos@uenf.br (RPRP)
This is an Open Access article distributed under the terms of the Creative Commons Attribution Non-Commercial License which permits unrestricted non-commercial use, distribution, and reproduction in any medium provided the original work is properly cited.

\begin{abstract}
The aim of this work is to evaluate the effectiveness of fiberglass and ceramic fiber cylinders as root-pass weld backing for a double-V groove in $16 \mathrm{~mm}$-thick carbon steel. Three different cylinder diameters were tested: $4.8,9.5 \mathrm{~mm}$ (fiberglass) and $6.4 \mathrm{~mm}$ (ceramic fiber). The welding process used was GMAW. The welding technique and the following process variables were investigated: root opening, current and travel speed. The results show that cylindrical fiberglass and ceramic fiber backings not only have excellent refractory properties, but also seal the root opening and contain the weld pool sufficiently to produce a root bead free of discontinuities and with a satisfactory shape and geometry. Working points were defined, together with a possible operating range for the welding parameters. It was concluded that cylindrical fiberglass and ceramic fiber weld backings hold great promise for use in root-pass welds in double-V grooves in applications in the naval and metallurgical industry.
\end{abstract}

Keywords: Root bead; Weld backing; Fiberglass; Ceramic fiber.

\section{Uso de Cilindros de Fibra de Vidro e Fibra Cerâmica como Material para Suporte do Passe de Raiz em Soldas de Aços C com Chanfro Duplo V}

Resumo: O objetivo deste trabalho é avaliar a eficiência da fibra de vidro e fibra cerâmica em formato cilíndrico como material para suporte de solda do passe de raiz em chanfro duplo $\checkmark$ em aço carbono de $16 \mathrm{~mm}$ de espessura. Foram testados dois diâmetros de cilindros de fibra de vidro (4,8 e 9,5 mm) e um de fibra cerâmica $(6,4 \mathrm{~mm})$. O processo GMAW foi usado sendo investigadas a técnica de soldagem e as seguintes variáveis do processo: abertura de raiz, corrente e velocidade de soldagem. Os resultados mostram que os suportes de solda cilíndricos de fibra de vidro e de fibra cerâmica, além de possuir excelentes propriedades refratárias, ofereceram vedação da abertura de raiz, contendo adequadamente a poça de solda fundida, produzindo um passe de raiz isento de descontinuidades, com adequado formato e geometria do cordão. Além de pontos de trabalho, foi delineada uma possível faixa de operação para os parâmetros de soldagem. Foi concluído que os suportes de solda a base de cilindros de fibra de vidro e de fibra cerâmica apresentam excelentes perspectivas para a soldagem do passe de raiz em chanfros duplo V em aplicações na indústria naval e no setor metal-mecânico.

Palavras-chave: Passe de raiz; Suporte de solda; Fibra de vidro; Fibra cerâmica.

\section{Introduction}

Weld backing is used when complete penetration of the weld is required during the root pass or when the base metal does not have sufficient mass to provide a shield that can support the weld pool.

Welding generates a large pool of molten metal that remains liquid for a relatively long time and must be supported until it has solidified completely [1]. Welding with a backing has the advantage of eliminating root gouging, which is required in conventional welding. The use of backing not only gives the bead surface a higher-quality finish, but also minimizes welding time and cost.

Although conventional ceramic backing currently used in welding operations has these advantages, because it is stiff and brittle it does not mold properly to the different weld groove shapes and is thus more suitable for straight grooves. In circumferential welds, articulated ceramic backing can only be used with diameters greater than $600 \mathrm{~mm}$ [2]. 
Fiberglass and ceramic fiber have properties and characteristics that are common to ceramic materials, suggesting that they could be suitable for use as weld backing. They have a high melting point of around $1760{ }^{\circ} \mathrm{C}$, slightly above that of steel; they are manufactured by melting silica and do not generate gases; they are available in a wide variety of different shapes and thicknesses; they are low-cost products and can be used to produce low-cost weld backing; and they are flexible and easily molded to any surface [3,4]. Few studies of fiberglass cloth [5-7] that identified the potential of this material for use as weld backing in the welding manufacturing industry were found in the literature.

The main aim of this study was to evaluate cylindrical fiberglass and ceramic fiber weld backing with different diameters during root-pass welding of butt joints with a double-V groove and identify the most suitable welding technique and process variables, as well as a possible process operating range. Only the root pass was investigated. The study is a novel one, as to the author's knowledge there are no references in the literature to the use of fiberglass and ceramic fiber cylinders in root-pass welds in double-V grooves. In light of this, the rationale behind the study was to develop cylindrical fiberglass and ceramic fiber weld backing with excellent refractory properties, mobility and flexibility for use in root openings.

\section{Materials and Methods}

The backings used in this study were made from woven strands of fiberglass and were cylindrical in shape with diameters of 4.8 and $9.5 \mathrm{~mm}$ (fiberglass) and $6.4 \mathrm{~mm}$ (ceramic fiber). They look like string and are shown in Figure 1. The chemical composition of the fiberglass is $52-56 \% \mathrm{SiO}_{2}, 12-16 \% \mathrm{Al}_{2} \mathrm{O}_{3}, 11-15 \% \mathrm{CaO}, 5-10 \% \mathrm{~B}_{2} \mathrm{O}_{3}$ and $0-6 \% \mathrm{MgO}$, while the composition of the ceramic fiber is $53 \% \mathrm{SiO}_{2}$ and $46 \% \mathrm{Al}_{2} \mathrm{O}_{3}$. The melting point of both fibers is $1760{ }^{\circ} \mathrm{C}$ [8].
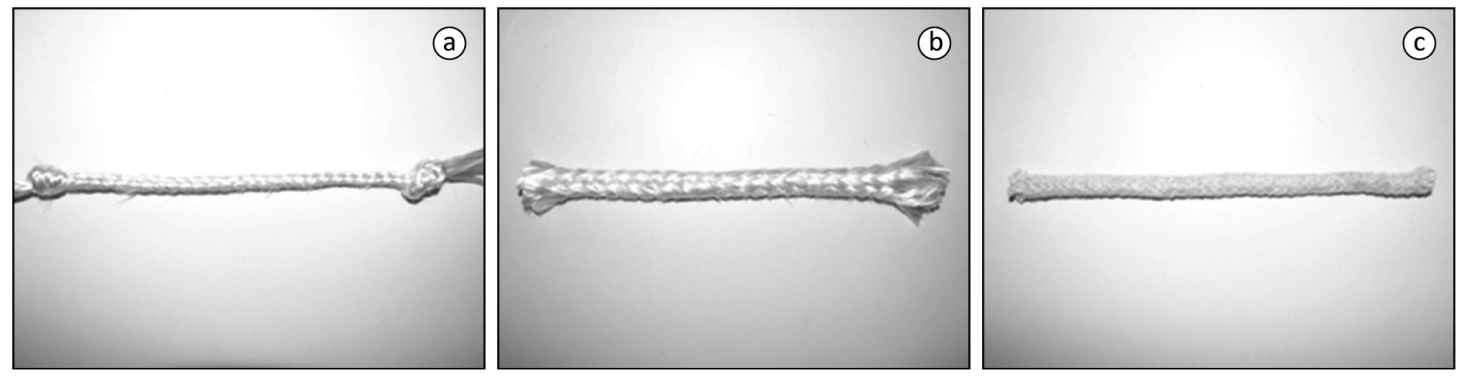

Figure 1. Cylindrical fiberglass weld backing with a diameter of $4.8 \mathrm{~mm}$ (a) and $9.5 \mathrm{~mm}$ (b) and ceramic fiber backing with a diameter of $6.4 \mathrm{~mm}$ (c).

ASTM A36 steel plates measuring $150 \times 50 \times 16 \mathrm{~mm}$ with a double-V $90^{\circ}$ groove and without any land were prepared, as shown in Figure 2a. The root opening was 0, 2.5 and $5.0 \mathrm{~mm}$. Joints were assembled using auxiliary plates made of the same steel at each end of the joint to keep the plates in place, the root opening constant and the whole structure firm. Figure $2 b$ shows an assembled joint ready for welding. The fiberglass and ceramic fiber backing was kept in place by pressure againt the root opening, as shown in Figure $2 \mathrm{~b}$.
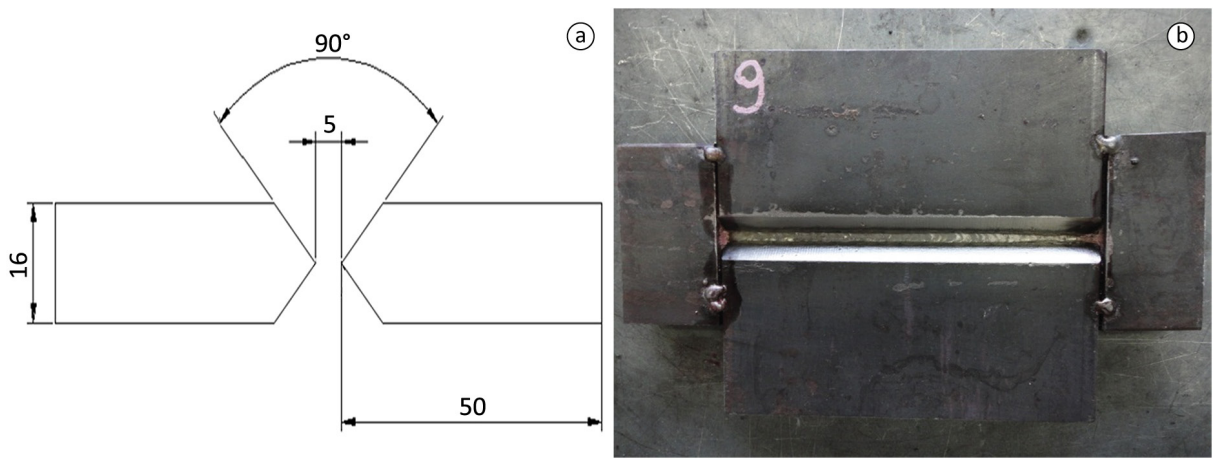

Figure 2. (a) Details of the groove used; (b) a prepared joint ready for welding. 
Only the root pass was welded. This was done using semi-automatic GMAW (gas metal arc welding) with ER70S-6 $1.0 \mathrm{~mm}$ diameter wire, $\mathrm{CO}_{2}$ shielding gas at a flow rate of $12 \mathrm{~L} / \mathrm{min}$ and a stick-out of 10 to $12 \mathrm{~mm}$. The joints were made with a small side-to-side oscillation of the torch. Table 1 shows the welding parameters used. The current $(A)$ and voltage $(V)$ values were read from the sensors in the welding machine during welding. Travel speed $(v)$ was calculated by dividing weld length by welding time. Heat input $(E)$ in $\mathrm{kJ} / \mathrm{mm}$ was calculated using the equation $E=$ ( $\eta$.V.A)/1000.v, where $\eta$ is the process efficiency (in this case $\eta=0.8$, a typical value for GMAW), $V$ and $A$ the weld voltage and current, respectively, and $v$ the travel speed. After welding, the fiberglass or ceramic fiber backing was removed manually.

Table 1. Welding parameters used in the experiments.

\begin{tabular}{|c|c|c|c|c|c|c|c|}
\hline Joint & $\begin{array}{l}\text { Root } \\
\text { opening } \\
\text { (mm) }\end{array}$ & $\begin{array}{l}\text { Backing } \\
\text { material }\end{array}$ & $\begin{array}{c}\text { Backing } \\
\text { diameter } \\
(\mathrm{mm})\end{array}$ & $\begin{array}{c}\text { Current } \\
\text { (A) }\end{array}$ & $\begin{array}{c}\text { Voltage } \\
\text { (V) }\end{array}$ & $\begin{array}{c}\text { Travel speed } \\
\text { (v) } \\
(\mathrm{mm} / \mathrm{s})\end{array}$ & $\begin{array}{l}\text { Heat input } \\
\text { (E) }(\mathrm{kJ} / \mathrm{mm})\end{array}$ \\
\hline 1 & 0 & FG & 4.8 & 200 & 26.2 & 3.6 & 1.2 \\
\hline 2 & 2.5 & FG & 4.8 & 108 & 19.1 & 1.1 & 1.5 \\
\hline 3 & 5.0 & CF & 6.4 & 100 & 19.4 & 0.8 & 1.9 \\
\hline 4 & 2.5 & FG & 4.8 & 152 & 21.6 & 1.9 & 1.4 \\
\hline 5 & 2.5 & CF & 6.4 & 152 & 21.6 & 1.8 & 1.5 \\
\hline 6 & 2.5 & FG & 9.5 & 152 & 21.4 & 1.8 & 1.5 \\
\hline 7 & 5.0 & FG & 9.5 & 152 & 21.4 & 1.4 & 1.9 \\
\hline 8 & 2.5 & FG & 4.8 & 216 & 27.8 & 3.1 & 1.5 \\
\hline 9 & 5.0 & CF & 6.4 & 204 & 28.0 & 1.7 & 2.7 \\
\hline 10 & 5.0 & FG & 9.5 & 204 & 28.0 & 1.9 & 2.4 \\
\hline
\end{tabular}

After the welds were made, the effectiveness of fiberglass (FG) and ceramic fiber (CF) in supporting the weld pool during the root pass was measured in two types of non-destructive tests: visual inspection (VI) and liquid penetrant testing (LP). The last $25 \mathrm{~mm}$ at the ends of each joint were discarded, and a $100 \mathrm{~mm}$ section in the middle of each weld bead was analyzed. VI and LP were performed on the surface of the root bead in contact with the weld backing. In this way, the quality of the root bead surface finish and any surface discontinuities could be identified. Macrographs of a cross section of the weld bead were produced to analyze the appearance and geometry of the root pass. The cross sections were ground to 400 mesh, and the surfaces etched with $10 \%$ nital. With the aid of a caliper, the macrographs were also used to measure the width of the root pass in contact with the weld backing and estimate the side penetration of the root pass.

The results were used for a qualitative analysis based on a graph with the following variables: diameter of the weld backing, root opening and heat input. The graph was used to identify a possible range of operating values for the process.

\section{Results and Discussion}

In this study FG and CF cylinders were tested as weld backing in GMAW welds in C-Mn steels with a double-V groove, and their effectiveness in supporting the weld pool during the root pass was evaluated. To observe the effect of different values of welding parameters on the welds, the following values were tested: weld backing diameter -4.8 and $9.5 \mathrm{~mm}$; root opening -0 to $5 \mathrm{~mm}$; weld current -100 to $216 \mathrm{~A}$ and travel speed -0.8 to $3.6 \mathrm{~mm} / \mathrm{s}$. The heat input varied from 1.2 to $2.7 \mathrm{~kJ} / \mathrm{mm}$.

After the welding had been completed, the weld backing could be easily removed as it had not stuck to the surface of the root weld although it had partially melted. There were no signs of gases being produced during welding, confirming the effectiveness of FG and CF as weld backing. With regard to the welding technique, it was established that the welder should use a backhand technique with a small side-to-side oscillation so that the electric arc is not always pointing at the weld backing. Straight-line welding should be avoided as this could cause the backing to move and a weld bead with the wrong shape to be produced. 
A detailed evaluation of the joints using VI and LP is given in Gurgel [9]: briefly, for joint 1, with a root opening of zero, LP revealed undercuts; for joint 10, with a root opening of $5.0 \mathrm{~mm}$, VI showed that there was leakage of the molten metal and excessive root reinforcement in the region of the bead in contact with the FG backing; and for joints 2 to $9, \mathrm{VI}$ and LP revealed a satisfactory root pass finish without any discontinuities such as cracks or undercuts. Based on the results of VI and LP, joints 1 and 10 were considered unacceptable, while joints 2 to 9 were deemed acceptable.

Macrographs of joints 1 to 10 are shown in Figure 3. The cross sections of the weld beads in joints 1 to 8 had a satisfactory appearance and an acceptable root pass geometry. These joints were therefore considered to have passed the macrographic examination. Joint 9 had an internal pore while joint 10 showed signs of leakage and marked irregularities on the surface of the root weld. These findings were also observed on $\mathrm{VI}$, and both joints were therefore considered to have failed the macrographic examination.

The results of VI and LP together with the macrographs show that FG and CF cylinders were generally both suitable and effective for use as weld backing in most of the joints with a double-V groove tested. Joints 2 to 8 were considered acceptable, and the root pass had a satisfactory finish free from discontinuities. The results presented here confirm the refractory potential of FG and CF as material for weld backing, particularly in this study of their applicability to a weld in a double-V groove in C-Mn steel. Joints 1, 9 and 10 are evaluated in detail below.

Joint 1, in Figure 3a, which was made without any root opening, was able to support the weld pool and had suitable geometry, as shown in the macrograph. However, LP revealed undercuts. According to Tatagiba et al. [6], in FCAW (flux-cored arc welding) with FG weld backing, the use of V-groove joints without a root opening has a tendency to produce welds with insufficient root penetration. As the use of joints without a root opening should therefore be avoided, joint 1 was considered unsatisfactory.

Joints 9 and 10, in Figure 3i, j, were made with a $5.0 \mathrm{~mm}$ root opening. Joint 9 has internal porosity, while joint 10 shows evidence of partial leakage of the molten metal. This can be attributed to failure of the $9.5 \mathrm{~mm}$-diameter FG backing to seal the root opening $(5.0 \mathrm{~mm})$ completely, resulting in the irregular shape of the root pass. As these joints were welded with a high energy input $(2.7 \mathrm{~kJ} / \mathrm{mm}$ for joint 7 and $2.4 \mathrm{~kJ} / \mathrm{mm}$ for joint 10), the results would indicate that these energy levels are not suitable for root-pass welding. Joints 9 and 10 were therefore considered unsatisfactory. Although joint 3 was also made with a $5.0 \mathrm{~mm}$ root opening and was considered satisfactory, it was concluded that this size root opening is at the limit of acceptable operating values.

The results of the non-destructive tests and micrographic test are similar to those reported by Tatagiba et al. [6] and Meller et al. [10]. The root pass geometry, without any undercuts, incomplete melting or cracks, is similar to that described by Barbedo [11].

Both FG, with a diameter of 4.8 and $9.5 \mathrm{~mm}$, and CF, with a diameter of $6.4 \mathrm{~mm}$, yielded satisfactory results.

The width of the root pass was measured directly from the macrographs using a caliper. Side penetration was measured by dividing the difference between the root bead width and root opening by two. Side penetration indicates how much of each face of the groove was melted during the root pass. Table 2 shows the dimensions measured from the macrographs.

The results in Table 2 show that there was side penetration in the walls of the double-V groove in all the joints.

For joint 1, which was made without a root opening, the root pass was $1.0 \mathrm{~mm}$ wide on the face in contact with the weld backing, and side penetration was estimated to be $0.5 \mathrm{~mm}$.

For a root opening of $2.5 \mathrm{~mm}$ (joints $2,4,5,6$ and 8 ), the width of the root pass on the face in contact with the weld backing was $3.0 \mathrm{~mm}$ for joint 2, which was made with a current of $108 \mathrm{~A}$ and had a side penetration of $0.3 \mathrm{~mm} ; 4.0 \mathrm{~mm}$ for joints 4, 5 and 6 , which were produced with a current of $152 \mathrm{~A}$ and had a side penetration of $0.8 \mathrm{~mm}$; and $2.7 \mathrm{~mm}$ for joint 8 , which was produced with a current of $216 \mathrm{~A}$ and had a side penetration of $0.1 \mathrm{~mm}$.

For a root opening of $5.0 \mathrm{~mm}$ (joints 3, 7, 9 and 10), the width of the root pass on the face in contact with the weld backing was $6.0 \mathrm{~mm}$ for joint 3 , which was made with a current of $100 \mathrm{~A}$ and had a side penetration of $0.5 \mathrm{~mm}$; and $7.0 \mathrm{~mm}$ for joint 7 , which was produced with a current of $152 \mathrm{~A}$ and had a side penetration of $1.0 \mathrm{~mm}$. When the current was increased to 204 A for joints 9 and 10, the width of the weld bead on the face in contact with the backing was 8.0 and $8.5 \mathrm{~mm}$, respectively, and the corresponding figures for side penetration in the base metal plates were 1.5 and $1.8 \mathrm{~mm}$. 


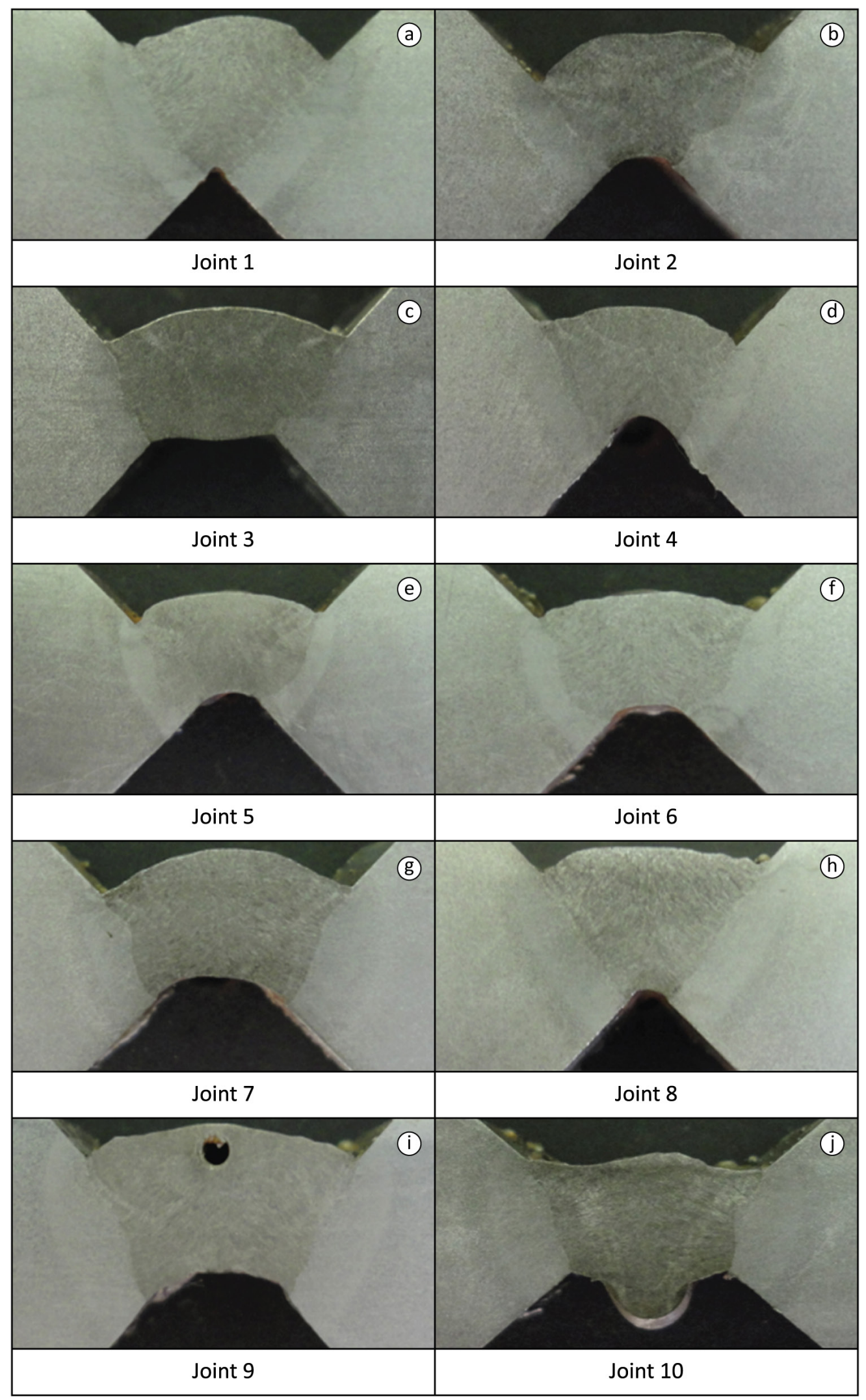

Figure 3. Macrographs of the welded joints. 
Table 2. Dimensions measured from the macrographs.

\begin{tabular}{ccccc}
\hline Joint & $\begin{array}{c}\text { Root opening } \\
(\mathbf{m m})\end{array}$ & $\begin{array}{c}\text { Backing diameter } \\
(\mathbf{m m})\end{array}$ & $\begin{array}{c}\text { Width of the root } \\
\text { pass }(\mathbf{m m})\end{array}$ & $\begin{array}{c}\text { Side penetration } \\
(\mathbf{m m})\end{array}$ \\
1 & 0.0 & 4.8 & 1.0 & 0.5 \\
2 & 2.5 & 4.8 & 3.0 & 0.3 \\
3 & 5.0 & 6.4 & 6.0 & 0.5 \\
4 & 2.5 & 4.8 & 4.0 & 0.8 \\
5 & 2.5 & 6.4 & 4.0 & 0.8 \\
6 & 2.5 & 9.5 & 4.0 & 0.8 \\
7 & 5.0 & 9.5 & 7.0 & 1.0 \\
8 & 2.5 & 4.8 & 2.7 & 0.1 \\
9 & 5.0 & 6.4 & 8.0 & 1.5 \\
10 & 5.0 & 9.5 & 8.5 & 1.8 \\
\hline
\end{tabular}

Travel speed was the other important parameter analyzed in the experimental procedure in this study. This parameter is known to determine the width of the weld bead and, therefore, side penetration in the joint plates [1]. It can be seen from Table 1 that for a given current, the travel speed decreased as the root opening increased. This is because the greater the root opening, the more filler metal needed to fill the root of the groove. The travel speed was therefore reduced by the welder to achieve this. For example, joints 4,5 and 6 , all of which had a root opening of $2.5 \mathrm{~mm}$, were welded with a current of $152 \mathrm{~A}$ and travel speed varying from 1.8 to $1.9 \mathrm{~mm} / \mathrm{s}$. For joint 7, in contrast, which had a root opening of $5.0 \mathrm{~mm}$ and was also welded with a current of $152 \mathrm{~A}$, the travel speed was $1.4 \mathrm{~mm} / \mathrm{s}$. In addition, the side penetration on the face in contact with the backing increased from $0.8 \mathrm{~mm}$ for joints 4,5 and 6 to $1.0 \mathrm{~mm}$ for joint 7. This behavior was observed whenever the root opening was increased. For a current in the region of $100 \mathrm{~A}$ (joints 2 and 3), the increase in root opening from 2.5 to $5.0 \mathrm{~mm}$ resulted in an increase in side penetration of the weld metal from 0.3 to $0.5 \mathrm{~mm}$ because of the reduction in travel speed from 1.1 to $0.8 \mathrm{~mm} / \mathrm{s}$, respectively. For a current of around $200 \mathrm{~A}$ (joints 8,9 and 10), the change in root opening from 2.5 to $5.0 \mathrm{~mm}$ increased the side penetration from $0.1 \mathrm{~mm}$ to $1.8 \mathrm{~mm}$, with a reduction in travel speed from $3.1 \mathrm{~mm} / \mathrm{s}$ to $1.7 \mathrm{~mm} / \mathrm{s}$.

Heat input behaved similarly to travel speed, i.e., it generally increased with increasing root opening. This is because as the root opening increases, more electrode needs to be melted to fill the groove sufficiently. For welding without a root opening (joint 1), heat input was $1.2 \mathrm{~kJ} / \mathrm{mm}$; for a root opening of $2.5 \mathrm{~mm}$ (joints 2, 4, 5, 6 and 8 ), the corresponding figure was in the range 1.4 to $1.5 \mathrm{~kJ} / \mathrm{mm}$; and for a root opening of $5.0 \mathrm{~mm}$ (joints 8,9 and 10), the figure was between 1.9 and $2.7 \mathrm{~kJ} / \mathrm{mm}$. However, it should be noted that with a heat input of more than $2.4 \mathrm{~kJ} / \mathrm{mm}$ (joints 9 and 10), the process has reached its operational limit and tends to produce welds with discontinuities and partial leakage of the molten metal.

In light of the above, the following statements can be made about the use of FG and CF weld backing when GMAW welding a root pass in a double-V groove in C-Mn steel:

(a) FG and CF in a cylindrical shape proved to be effective weld backing for root welds;

(b) the greater the root opening, the greater the width of the root pass in contact with the weld backing and the greater the side penetration of the root pass in the groove edges;

(c) the greater the weld current, the greater the width of the root pass and the greater the side penetration of the root pass;

(d) a reduction in travel speed and an increase in heat input produce an increase in the width of the root pass in contact with the weld backing and an increase in the side penetration of the weld in the base metal plates.

Based on the behavior described above, a potential operating range was established for root pass GMAW welds in double-V groove butt joints in C-Mn steel using cylindrical FG and CF weld backing, $1.0 \mathrm{~mm}$-diameter ER70S- 6 wire and $\mathrm{CO}_{2}$ shielding gas with a flow rate of $12 \mathrm{l} / \mathrm{min}$, as shown in Figure 4 . The potential values of the main welding variables for this operating range were: 


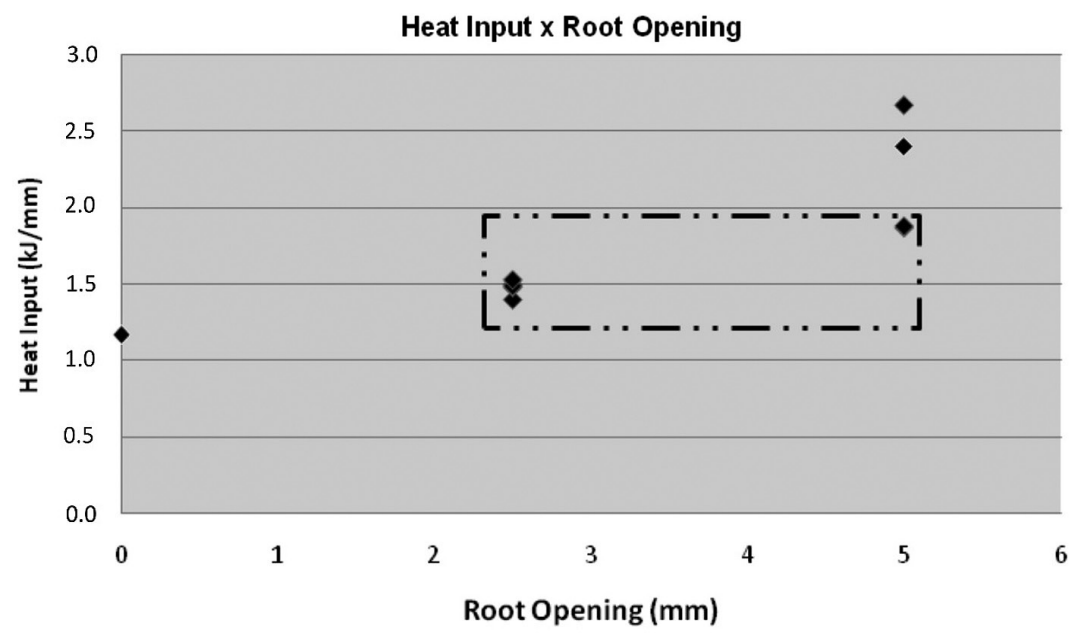

Figure 4. Graph of heat input against root opening showing a possible operating range for the process.

- heat input: 1.4 to $2.0 \mathrm{~kJ} / \mathrm{mm}$;

- root opening: 2.5 to $5.0 \mathrm{~mm}$;

- welding technique: small side-to-side oscillation;

- weld-backing diameter: FG - 4.8 and 9.5 mm; CF - $6.4 \mathrm{~mm}$.

The estimated operating range is similar to that reported by Tatagiba $[5,6]$ for single-sided welding with flat fiberglass backing and also to that used for welding with conventional ceramic backing [12,13]. In addition, the non-destructive tests carried out within this range of welding parameters failed to detect discontinuities such as inclusions, cracks, pores and undercuts along the weld bead. The macrographs showed penetration into the sides of the groove, acceptable weld reinforcement and an absence of discontinuities.

The results reported here show the effectiveness of GF and CF cylinders as weld backing for root-pass welds in thick plates with a double-V groove. The following advantages can be observed:

- FG and CF cylinders are very flexible. They could therefore be secured in the groove by pressure alone and still provide satisfactory sealing along the whole length of the joint root, making adhesive tape unnecessary. Furthermore, conventional ceramic backing can only be used with diameters above $600 \mathrm{~mm}$ [2] whereas cylindrical FG and CF backing is suitable for use with much smaller diameters because of its excellent flexibility, which enables it to be bent and folded;

- another advantage of using cylindrical backing for root-pass welds in a double-V groove is that root gouging followed by grinding and non-destructive tests, which are required after conventional welding, are not needed. The use of cylindrical FG or CF weld backing allows the root pass to be deposited with satisfactory quality, shape and surface finish. Because of these characteristics, root-pass welding in a double-V groove with cylindrical FG and CF weld backing is more productive and requires less time, leading to significant operational cost savings [5].

Finally, the results of this study on the use of FG and CF cylinders in root-pass welds in double-V grooves, together with the results of the study by Tatagiba [5] on the use of weld backing made from FG and CF cloth, led to the filing of patent PI1104772-0 [14] with the National Industrial Property Institue (INPI).

\section{Conclusions}

It can be concluded from this study on the use of FG and CF cylinders as weld backing in double-V groove root-pass GMAW welds in C-Mn steel that FG cylinders with diameters of 4.8 and $9.5 \mathrm{~mm}$ and CF cylinders with a diameter of $6.4 \mathrm{~mm}$ were able to provide effective support for the weld pool. No gases were formed during welding, and a root-pass weld with a satisfactory finish and no discontinuities was produced. 
The following potential range of operating parameters demonstrating the effectiveness of cylindrical FG backing was estimated: a root opening of 2.5 to $5.0 \mathrm{~mm}$ and a heat input of 1.4 to $2.0 \mathrm{~kJ} / \mathrm{mm}$ using backhand welding with a slight side-to-side oscillation.

\section{Acknowledgements}

The authors would like to thank CNPq for supporting this study.

\section{References}

[1] Paranhos RPR, Souza AC. Soldagem a arco submerso. Rio de Janeiro: FIRJAN/SENAl; 1999. 87 p. (Coleção Soldagem 2000).

[2] Xiangshan Welding Backing Factory. Catálogo de produtos [página da internet]. Zhejiang: Welding Backing Factory. [access in: 23 june 2010]. Available from: http://www.chinabacking. com/en/products.php.

[3] Callister WD Jr. Ciencia e engenharia de materiais: uma introdução. São Paulo: LTC Editora; 2002. 589 p.

[4] Chawla KK. Ceramic matrix composites. London: Chapman \& Hall; 1993. 415 p.

[5] Tatagiba LCS. Desenvolvimento de suporte de solda à base de fibra de vidro. [master's dissertation]. Campos dos Goytacazes: Universidade Estadual do Norte Fluminense Darcy Ribeiro; 2009. $94 \mathrm{p}$.

[6] Tatagiba, LCS, Silva, AGP, Paranhos, RPR. Investigação sobre a eficiência da fibra de vidro e da fibra cerâmica como suporte de solda na soldagem unilateral. Soldagem \& Inspeção. 2011;16(4):377-386.

[7] Tatagiba, LCS, Silva, AGP, Paranhos, RPR. Caracterização de uma junta soldada com suporte de solda a base de fibra de vidro. Soldagem \& Inspeção. 2012;17(1):11-18.

[8] Texiglass. Fixa técnica de tecidos. São Paulo: Maxepoxi Industrial e Comercial Ltda. [access in: 12 july 2011]. Available from: http:// www.maxepoxi.com.br/tecnica tecidos.asp.

[9] Gurgel RF. Desenvolvimento de suporte de solda à base de cordas de fibra de vidro e fibra cerâmica, para aplicação em soldas duplo "V" de elevada produtividade. [master's dissertation]. Campos dos Goytacazes: Universidade Estadual do Norte Fluminense Darcy Ribeiro; 2013. 119 p.

[10] Meller RN, Costenaro F, Carvalho RS, Silva RHG, Dutra JC. Desenvolvimento e análise de procedimentos de soldagem orbital mecanizada por intermédio de manipulador robótico para a união de dutos. In: Anais do 370 Congresso Nacional de Soldagem; 2011 Oct 3-6; Natal, Brazil. São Paulo: Associação Brasileira da Soldagem; 2011.

[11] Barbedo NDD. Avaliação comparativa dos processos de soldagem GMAW e FCAW utilizando aço ASTM a-36 para verificar a soldabilidade, propriedades metalúrgicas e geométricas, e resistência. [master's dissertation]. Itajubá: Universidade Federal de Itajubá; 2011.68 p.

[12] Almeida LLP, Tatagiba LCS, Rosenthal R, Paranhos RPR. Soldagem unilateral com suporte cerâmico de cordierita. Soldagem \& Inspeção. 2010;15(1):61-70. http://dx.doi.org/10.1590/S010492242010000100008 .

[13] Andrade ST. Mapeamento do processo mecanizado de soldagem unilateral FCAW com backing cerâmico aplicável no passe de raiz em aço carbono. [master's dissertation]. Belo Horizonte: Universidade Federal de Minas Gerais; 2007. 103 p.

[14] Tatagiba, LCS, Gurgel, RF, Paranhos, RPR. inventors. Suporte de solda flexível a base de tecido e corda de fibra de vidro e fibra cerâmica. PI1104772-0. 2011 Sept 14. 